\title{
SKELETAL MUSCLE ANALYSIS OF WHEELCHAIR ATHLETES ${ }^{1}$
}

\author{
By A. W. Taylor, Ph.D., D.Sc., ${ }^{\star}$ E. McDonnell, M.Sc., ${ }^{\star}$ D. Royer, Ph.D., $\dagger$ \\ R. LoIselle, M.Sc., $\ddagger$ N. Lush, M.D. $\$$ and R. Steadward, Ph.D. $\mid$ \\ * University of Montreal; $\dagger$ University of Sherbrooke, Quebec; $\ddagger$ Department of Sport for the \\ Physically Disabled, Ottawa; § St Fohns General Hospital, St Fohns, Nfld.; || University \\ of Alberta, Edmonton, Alberta
}

Abstract. The present study reports the results of using the biopsy technique with members of the Canadian Wheelchair International Team. The results demonstrate that these athletes possess muscles with larger fibre areas than seen in Olympic athletes.

Key words: Skeletal muscles analysis; Biopsy technique.

\section{Introduction}

DISABLED sports are a rather recent development in the long history of sporting competition (Canadian Games, I97I). The rapid growth resulted from the need to assist and prolong the life expectancy of the many victims of World War II. The first Stoke Mandeville Games for the disabled were held in 1948 but Canadian disabled athletes did not enter serious competition until 1967. Since that time these athletes have achieved world standards in several events.

Since the advent of the Bergstrom muscle biopsy technique (Bergstrom, I962) skeletal muscle analysis of world class and Olympic athletes has occurred on a regular basis. Sport scientists assess the energy subtrate concentrations (Hermansen et al., I967; Taylor et al., I97I; Bergstrom, 1976) and the activity levels of numerous metabolic marker enzymes (Gollnick et al., I972; Gollnick et al., 1973; Saltin, 1973, and Taylor, 1975). The resultant data has been used to improve training programmes, dietary regimens and ultimately the productivity of the athletes (Bergstrom et al., I967; Hultman, I967; Hultman, I978; Taylor et al., I978). To date no literature is available of similar studies with wheelchair athletes. The purpose of the present study is to report on the muscle morphology, and enzyme activities of biopsy samples from world class wheelchair athletes.

\section{Methods and Materials}

Skeletal muscle biopsy samples were taken from either the triceps lateralis or vastus lateralis of six wheelchair athletes immediately prior to the Invitational Games for Handicapped Athletes held at Ville d'Anjou, Québec in September of I978. The muscle samples were immediately analysed for the following parameters: morphology-fibre distribution and area by means of the DPNH histochemical stain (Novikoff, I96I) and a Zeiss particle counter; histochemical ATPase (Padykula, I955); SDH activity (Castill, I976); and PFK activity (Bergmeyer, I974).

1 Supported in part by a grant from the Canadian Association for Sport for the Physically Disabled, Ottawa, and Fonds de Soutien, University of Montreal. 


\section{Results}

The results of the muscle morphology are found in Table I. A large variability in fibre distribution was evident but this is similar to other previously published data (Gollnick et al., I972) and is not related to the classification of the subjects. Subjects were classed as to the International Stoke-Mandeville Games System where D signifies one-leg amputee above the knee joint, Class IV signifies a lesion below TIO to $\mathrm{T}_{13}$ inclusive, provided that quadriceps power is nonfunctional, and Class V signifies a lesion below $L_{3}$ to $S_{2}$ inclusive, provided that quadriceps function is M.R.C. Grade 3 and above. The fibre area of all slow twitch (ST) fibres range from average to very large when compared with data from Olympic athletes. The fast twitch (FT) areas are the largest measured to date in healthy human muscle (Table I).

Table II contains the enzyme activity levels for muscle homogenates. Both SDH and PFK activities are only average or much below average for highly trained 'normal' athletes.

\section{Discussion}

Few published articles exist (Ekblom \& Lundberg, I968; Knutsson, 1973; Nilsson, 1975) which are related to specific sport training for wheelchair athletes. Nilsson et al. have been able to show that training results in increases in maximal aerobic power, maximal work capacity, mechanical efficiency, and the subjective well-being of paraplegic patients. It is well documented (Gordon \& Vanderwalde, 1956; Brattgard et al. 1970) that walking with crutches and constant wheelchair use are less efficient and require more energy expenditure than normal walking. The results of the present study demonstrate, also, that these two modes of ambulation produce extremely large skeletal muscle fibre areas, at least in the triceps lateralis. This finding has significant implications for the normal athletes. Olympic athletes are reputed to practise for intensive time periods daily for several months each year and yet the size of fibres measured from these athletes does not

\section{TABLE I}

Fibre area and distribution of skeletal muscle biopsies

from handicapped athletes

\begin{tabular}{|c|c|c|c|c|c|c|c|c|}
\hline \multirow{2}{*}{ Athlete } & \multirow{2}{*}{ Age } & \multirow{2}{*}{ Sex } & \multirow{2}{*}{ Class } & \multirow{2}{*}{ Muscle } & \multirow{2}{*}{$\begin{array}{c}\text { Distribution } \\
\mathrm{ST} \%\end{array}$} & \multicolumn{3}{|c|}{ Area } \\
\hline & & & & & & FT & ST & Event \\
\hline \multirow[t]{2}{*}{ M. F. } & \multirow[t]{2}{*}{25} & \multirow[t]{2}{*}{ M } & \multirow[t]{2}{*}{5} & Triceps & 55 & I 5,349 & 6,649 & \multirow{7}{*}{$\begin{array}{l}\text { Track } \\
\text { Track } \\
\text { H.J. } \\
\text { T. \& F. } \\
\text { T, B-Ball } \\
\text { Field }\end{array}$} \\
\hline & & & & V. Lateralis & 37 & I6,074 & 9,965 & \\
\hline R. M. ${ }^{1}$ & 40 & $M$ & 4 & Triceps & I9 & I 8,67I & II 619 & \\
\hline A. B. & $2 I$ & M & D & V. Lateralis & 47 & 9,296 & 6,339 & \\
\hline A. V. & 25 & $M$ & 4 & Triceps & 54 & 17,386 & 12,502 & \\
\hline R. M. ${ }^{2}$ & 20 & $M$ & 4 & Triceps & 57 & 14,712 & II, 683 & \\
\hline \multirow[t]{3}{*}{ D. P. } & 30 & $\mathrm{~F}$ & 5 & Triceps & $6 I$ & I 4,622 & I I,960 & \\
\hline & & & & \multirow{2}{*}{$\begin{array}{l}\overline{\mathrm{X}} \text { (Triceps) } \\
\overline{\mathrm{X}} \text { (V.L.) }\end{array}$} & 49 & I6, I 48 & I0,873 & - \\
\hline & & & & & 42 & 12,685 & 8,152 & - \\
\hline
\end{tabular}

$\star$ Values are measured in $\mu \mathrm{m}^{2}$. 


\section{TABLE II}

SDH and PFK activities from skeletal muscle biopsy homogenates of handicapped athletes

\begin{tabular}{|c|c|c|c|c|c|c|c|}
\hline Athlete & Age & Sex & Class & Muscle & $\mathrm{SDH}$ & PFK & Event \\
\hline M. F. & 25 & M & 5 & $\begin{array}{l}\text { Triceps } \\
\text { V. Lateralis }\end{array}$ & - & $\begin{array}{l}\text { II.5 } \\
24.5\end{array}$ & Track \\
\hline R. M. ${ }^{1}$ & 40 & $M$ & 4 & Triceps & $\begin{array}{l}4.4 \\
7 \cdot 1\end{array}$ & 12 & Track \\
\hline A. B. & $2 \mathrm{I}$ & $M$ & $\mathrm{D}$ & V. Lateralis & $5 \cdot 2$ & 20 & H.J. \\
\hline A. V. & 25 & $M$ & 4 & Triceps & II $\cdot 0$ & II & T. \& F. \\
\hline R. M. ${ }^{2}$ & 20 & M & 4 & Triceps & I5 I & $17 \cdot 5$ & $\mathrm{~T}, \mathrm{~B}-\mathrm{Ball}$ \\
\hline \multirow[t]{3}{*}{ D. P. } & 30 & $\mathrm{~F}$ & 5 & Triceps & $7 \cdot I$ & $15 \cdot 0$ & Field \\
\hline & & & & $\overline{\mathrm{X}}$ (Triceps) & $10 \cdot 0$ & $13 \cdot 4$ & - \\
\hline & & & & $\bar{X}($ V.L. $)$ & $4 \cdot 8$ & $22 \cdot 2$ & - \\
\hline
\end{tabular}

Values are measured in $M$ moles/g/min (IU).

approach those found in the present study (Gollnick, 1973; Burke, 1977). The suggestion is that perhaps these athletes are not training for specific hypertrophy of the most important extensor muscle of the upper arm. Since the strength of a muscle is directly proportional to the cross-sectional area of the individual fibres then strength-related events require muscle hypertrophy as well as increased skill levels. Furthermore it appears that wheelchair athletes have inadvertently discovered a successful training method to produce muscle hypertrophy.

Although the muscle hypertrophy was prevalent in these subjects, the enzyme activities of SDH and PFK were relatively low when compared with trained normal subjects (Gollnick et al., I972; Gollnick et al., 1973, Burke et al., I977; Taylor et al., 1978). The comparatively low enzyme activities of both the marker enzymes for the oxidative pathway (SDH) and the glycolytic pathway (PFK) indicate that the intensity of the training programmes for these athletes and perhaps the duration and frequency, were not sufficient to result in the high values found in highly trained normal subjects. Even though the athletic results of these subjects were of world calibre, the inference must be that a more adequate, specific and intensified training programme would undoubtedly result in increased enzyme activities and probably greater athletic achievement.

Presently we are intensifying our research programme with Canadian wheelchair athletes and are attempting to establish specific training programmes for individual athletes. The biopsy technique coupled with studies of work capacity will undoubtedly aid the performance of these athletes.

\section{SUMMARY}

Few studies exist which have looked at the effects of physical training with wheelchair athletes. Since the inception of the muscle biopsy needle numerous studies have been carried out with world-class and Olympic athletes on skeletal muscle morphology, substrate levels and enzyme activities. The present study reports the results of using the biopsy technique with members of the Canadian Wheel-Chair International Team. The results demonstrate that these athletes 
possess muscles with larger fibre areas than seen in Olympic athletes. However, the enzyme activities (SDH, PFK) in the muscles are only average or low. The data suggest that the training programmes of the athletes are insufficient to bring about the enzyme activity levels found in Olympic athletes.

\section{RÉSUMÉ}

Peu de recherches ont été effectuées quant aux effets de l'entraînement physique chez les athlètes en chaise roulante. Depuis l'avènement de la biopsie musculaire, de nombreuses études ont été entreprises sur la morphologie musculaire, la teneur en substrats énergétiques et l'activité enzymatique des athlètes de calibre olympique et de classe internationale. Cette étude porte sur les résultats obtenus à l'aide de la technique de la biopsie musculaire chez les membres de l'Equipe internationale canadienne d'athlètes en chaise roulante. Nous observons que ces athlètes possèdent une musculature dont les fibres ont une surface supérieure à celle des athlètes olympiques. Cependant, l'activité des enzymes (SDH, PFK) dans le muscle est moyenne ou inférieure à celle des athlète de calibre olympique. Nos données suggèrent que les programmes d'entraînement des athlètes en chaise roulante ne sont pas d'intensité suffisante pour leur permettre d'atteindre les niveaux d'activité enzymatique des athlètes olympiques.

\section{ZUSAMMENFASSUNG}

Seit der Einführung der Technik von Muskel-Biopsy zahlreiche Studien an skeletal Morphologie, Substrat und Enzyme-Aktivität sind an Welt-klass und Olympischen Sportler ausgeführt worden. Die jetzige Studie gibt Resultate mit dieser Methode, die am Kanadischen internationalen Rollstuhl Team ausgefürt wurden. Diese Sportler zeigen grössere Muskelfasern als die Olympischen Sportler. Dagegen zeigten die Enzymaktivitäten (SDH, PFK) nur mittel oder geringe Werte im Vergleich mit Olympischen Sportlern.

\section{REFERENCES}

Bergmeyer, U. (1974). In Methods of Enzymatic Analysis, p. 45I. Academic Press, New York, U.S.A.

Bergstrom, J. (1962). Scand. F. Clin. Lab. Invest., Suppl. 68.

Bergstrom, J. \& Hultman, E. (1967). Scand. f. Clin. Lab. Invest., 19, 218-228.

Bergstrom, J., Hermansen, L., Hultman, E. \& Saltin, B. (1967). Acta Physiol. Scand., 7I, I 40-I 50.

Brattgard, S. O., Grimsy, G. \& Hodic, O. (1970). Scand. F. Rehab. Med., 2, I43-I47.

Burke, E. R., Cerny, F., Costill, D. \& Fink, W. (1977). Med. Sc. Sports, 9, IO9-I I2.

Canadian Games for the Physically Disabled (1977). University of Alberta Press, p. I3.

Costill, D. L., Fink, W. J. \& Pollock, M. L. (I976). Med. Sc. Sports, 8, 96-Ioo.

Ekblom, B. \& Lundberg, A. (I968). Acta Paed. Scand., 57, I7-23.

Gollnick, P. D., Armstrong, R. B., Saltin, B., et al. (I973). F. Appl. Physiol., 34, I07I I I.

Gollnick, P. D., Armstrong, R. B., Saubert IV, L. W., et al. (1972). F. Appl. Physiol., 33, 3I2-3I9.

Gordon, E. E. \& Vanderwalde, H. (1956). Arch. Phys. Med., 37, 276-287.

Hermansen, L., Hultman, E. \& Saltin, B. (I967). Acta Physiol. Scand., 71, I29-139.

Hultman, E. (1967). Scand. f. Clin. Lab. Invest., supp., 94, I-63.

Hultman, E. (1978). In 3rd International Symposium on Biochemistry of Exercise, pp. 99I26. Symposium Specialists, Miami, Fla., U.S.A.

Knutsson, E., Lewenhaupt-Olsson, E. \& Thorsen, M. (1973). Paraplegia, I1, 205-2ir6.

Nilsson, S., Staff, P. H. \& Pruett, E. D. R. (1975). Scand. F. Rehab. Med., 7, 5 I-56.

Novikoff, A. B., Shin, W. \& Drucher, J. (I96I). F. Biophys. Biochem. Cytol., 9, 47-6I.

Padykula, H. A. \& Herman, E. (I955). F. Histochem. Cytochem., 3, I70-I95.

Saltin, B. (1973). Med. Sci. Sports, 5, I37-146.

Taylor, A. W. (1975). In Metabolic Adaptation to Prolonged Physical Exercise, pp. 45I462. Birkhauser, Basel. 
Taylor, A. W., Lavoie, S., Lemieux, G., Dufresne, C., et al. (1978). In 3rd International Symposium on Biochemistry of Exercise, pp. 267-278. Symposium Specialists, Miami, Fla., U.S.A.

Taylor, A. W., Lappage, R. \& Rao, S. (I97I). Med. Sci. Sports., 3, 75-78.

Tuttle, W. W. \& Schottelius, B. A. (I969). Textbook of Physiology, p. 97. C. V. Mosby, St Louis. 